\title{
Correlation of Paleotectonic Fracture and Microfracture Orientations in Cores With Seismic Anisotropy at Cajon Pass Drill Hole, Southern California
}

\author{
T. G. BLENKINSOP ${ }^{1}$ \\ Institule for Crustal Studies, University of California, Santa Barbara
}

\begin{abstract}
Fractures and microfractures in oriented cores from the Cajon Pass drill hole, southern California, have strong preferred orientations. There are two major sets of extensional fractures and microfractures that have northwest and northeast strikes and vertical dips. Relative and absolute densities of both sets vary greatly within a single core. The regional tectonic history implies that these fractures and microfractures probably formed before late MiocenePliocene. Vertical seismic profiling experiments in the drill hole show shear wave splitting with polarization directions parallel to the fracture and microfracture orientations. The measured seismic anisotropy is due to these inherited deformation fabrics and does not appear to be caused by the current local stress field.
\end{abstract}

\section{INTRODUCTION}

During the last decade, a number of studies have looked for and detected seismic anisotropy in both $P$ and $S$ waves in the upper crust [e.g. , Crampin, 1978; Crampin et al., 1980a,b; Babuska and Pros, 1984; Maslova and Obolentseva, 1984; Nikitin and Chesnokov, 1984; Crampin et al., 1986; Davis and Clowes, 1986; Bennett and Smith, 1988; Savage et al., this issue]. The anisotropy has been attributed to aligned fractures by comparison of seismic measurements with theoretical models that treat the fractured crust as an anisotropic elastic solid [Crampin, 1978, 1981, 1984a,b; Crampin and Kirkwood, 1981; Hudson, 1980, 1981]. $S$ wave anisotropy is caused by splitting of $S$ waves into two orthogonally polarized directions, parallel and perpendicular to the fractures. For shear waves travelling in the plane of the fractures, the $S$ wave vibrating parallel to the fractures has a faster velocity than the wave vibrating perpendicular to the fractures, and this form of anisotropy causes a relative delay in arrival times between the two $S$ wave polarizations (see, for example, Crampin [1978] or Li et al. [1988]). An exciting aspect of this research is the relation between seismic anisotropy, fault zone structure, and seismicity, discussed by Crampin et al. [1984] and Evans [1984]. There is even some possibility that temporal changes in seismic anisotropy have been detected, which offers a promising approach to earthquake prediction [Crampinet al., 1980a, this issue; Peacock et al., 1988].

These studies have usually attributed the seismic anisotropy to monoplanar, vertical fractures or microfractures that form normal to the least principal in situ stress. However, deducing crustal properties from seismic data is usually an indeterminate problem, due to the large number of variables, which include the number and orientation of the fracture sets, the fracture dimensions, fracture densities, elastic properties of the fractures and their fillings, and pore fluid pressures. The fracture/microfracture distribution is usually inferred or as sumed and has not been compared to independent geological observations. The Cajon Pass drill hole in southern California provides an excellent opportunity to make this comparison.

\footnotetext{
' Now at Department of Geology, University of Zimbabwe, Harare.

Copyright 1990 by the American Geophysical Union.
}

The 3.5-km-deep Cajon Pass drill hole is situated between the San Gabriel and San Bernardino mountains in the Western Transverse ranges of southern California (Figure 1). It lies $4 \mathrm{~km}$ northeast of the San Andreas fault and was designed to address the heat flow stress paradox [Zobacket al., 1988], as well as related problems of regional tectonics and the physical properties of the upper crust. A total of 54 cores were taken to a depth of $3510 \mathrm{~m}$, sampling coarse arenaceous sediments to about $500 \mathrm{~m}$ before reaching crystalline basement rocks including granites, granodiorites, gabbros, migmatites, and gneisses [Silver and James, 1988].

Seismic anisotropy around the drill hole has been measured by four separate groups [Bush and Crampin, 1988; Daley et al., 1988; Li et al., 1988; Rector, 1988]. Orientated cores from the drill hole examined in this study show two dominant fracture/microfracture orientations with variable densities. The fractures/microfractures were probably formed before an episode of late Miocene-Pliocene reverse shear deformation [Blenkinsop and Sibson, 1988]. The bulk of the borehole seismic observations indicate that the fractures/microfractures control the seismic anisotropy. This suggests that the polarizations are not primarily due to the current stress field.

\section{Quantitative Description of Fractures AND MiCROFRACTURES}

The maximum ( $a$, length), intermediate $(b)$, and minimum ( $c$, width) dimensions of fractures and microfractures have been measured directly from the core and in thin sections, allowing estimates to be made of ellipticity $(a / b)$ and aspect ratio $(c / a)$. Fracture and $\mathrm{mi}-$ crofracture fillings were recorded. The microscopic observations were made on a Nikon Optiphot-Pol microscope at $x 40$. To exclude the non tectonic influence of cleavage, intragranular microfractures were measured only in quartz, which does not have a significant cleavage; otherwise, transgranular microfractures were measured, in which the effect of cleavage could be discounted because the microfracture trace was straight across several grains of different orientations and compositions. Non systematic open microfractures that could have been caused by section preparation were also excluded. From 10 to 60 microfractures (average 37) were measured from each of 34 sections.

This study examines cores in the interval $521-1744 \mathrm{~m}$ of the Cajon Pass drill hole (cores 5-20), which have been orientated by comparing fractures in the core with orientated electrical logs [Pezard and Luthi, 1988; Pezard et al., 1988]. Fracture orientations were measured directly from the core, and microfracture orientations were determined from horizontally and vertically orientated thin sections. 


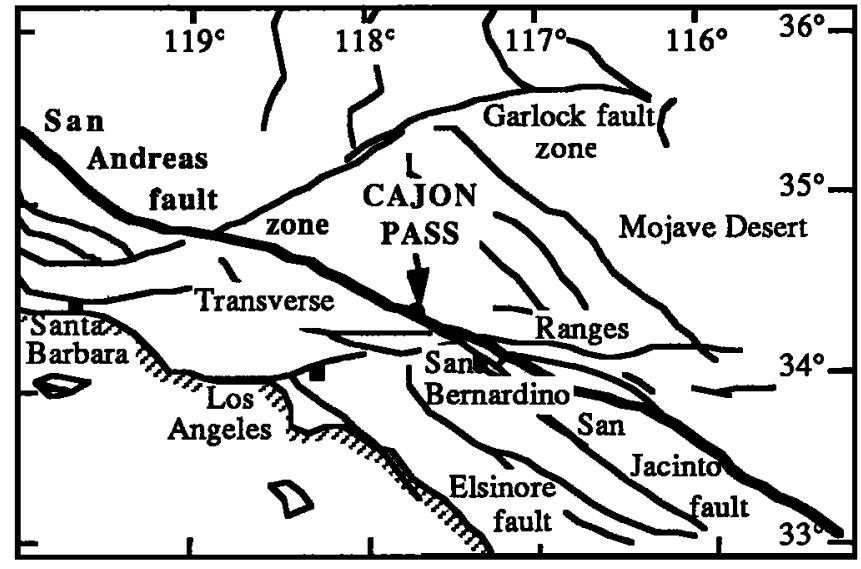

Fig.1. Location of the Cajon Pass scientific drill hole, Califomia.

These microfracture number orientations were weighted by microfracture area to convert them to microfracture density orientations, which express the effect of microfractures on anisotropy more accurately. In the density orientations, the frequency of microfractures in a $10^{\circ}$ interval is given by the sum the square of the length of each microfracture, normalized by the total of squared microfracture lengths.

Microfracture densities were measured in thin section by counting the number of microfractures/unit area $(M)$. These can be expressed in terms of the crack density parameter $\varepsilon$, following O'Connell and Budiansky [1974], who demonstrate that given a range of microfracture sizes and shapes that are not correlated and ellipticities of less than 10 , the following relationship holds. For $\left\langle a^{2}\right\rangle$ denoting the mean of the squares of the microfracture lengths:

$$
\varepsilon=\frac{3 M\left\langle a^{2}\right\rangle}{4 \pi}
$$

\section{Fractures and Microfractures in the Crystalline Basement of the Cajon Pass Drillhole}

The rocks in the study interval are homblende-sphene biotite granodiorite, alkali feldspar porphyritic granite, some metasedimentary gneisses, and granitic and granodioritic gneisses, juxtaposed along fault and intrusive contacts [Silver and James, 1988]. The major deformation features are cataclastic, including mode I fractures and microfractures, as well as both reverse and normal component shear fractures [Blenkinsop and Sibson, 1988]. Reverse component shear fractures are localized at depths from 521 to $721 \mathrm{~m}$ and 1351 to $1357 \mathrm{~m}$, whereas mode I (extensional) fractures and microfractures are ubiquitous throughout the interval. These mode Imicrofractures and fractures are described in more detail below because of their possible influence on seismic anisotropy.

The microfractures have maximum dimensions from 0.25 to 25 $\mathrm{mm}$, minimum dimensions from less than $0.01 \mathrm{~mm}$ up to $1 \mathrm{~mm}$, and aspect ratios from 0.002 to 0.5 (Table 1 ). They are both intergranular and intragranular, and all microfractures have pure mode I displacements. Most microfractures are seen as planes of isolated pores with convex-inward boundaries or fluid inclusions in quartz or feldspar crystals, indicating that the microfractures are largely cemented, as described, for example, in cataclastically deformed quartzites by Blenkinsop and Rutter [1986] and reported in a "quartzose gneiss" sample at $1284 \mathrm{~m}$ (core 16) from the Cajon Pass drill hole by Morrow and Byerlee [1988]. Such fluid inclusions are formed by incomplete healing of microfractures by diffusion. This process leaves behind isolated tubes containing the cementing fluid, which subsequently
TABLE 1. Fracture and Microfracture Characteristics of the Cajon Pass Core

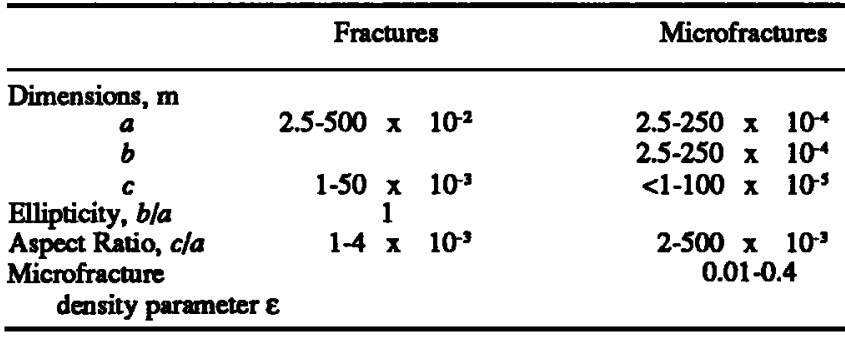

either ovulate (form two or more bubbles) or spheroidize (form a single bubble) [Smith and Evans, 1984]. The open pores are best interpreted as decrepitated fluid inclusions (J. L. R. Touret, personal communication, 1989). Figure $2 a$ illustrates the two approximately orthogonal sets of these cemented microfractures. Other microfractures have epidote or laumontite and/or calcite fills. Figure $3 a$ shows rose diagrams of the total data set of microfracture density orientations in horizontal sections ( 862 microfractures), which are divided into a dominant set striking northwest, and a subordinate set striking northeast (Figures $3 b$ and $3 c$ ). In the vertical sections (Figure $3 d$ ), the
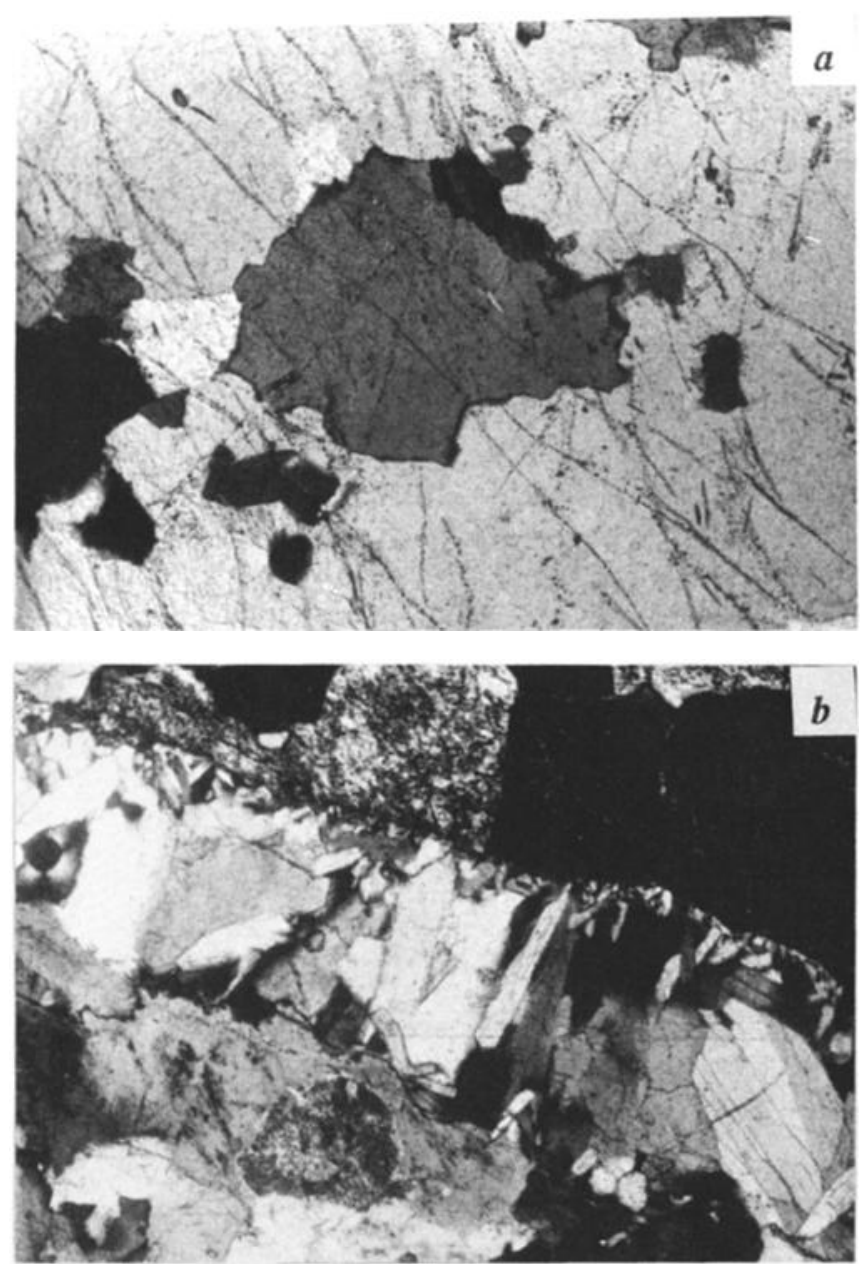

Fig. 2.(a) Mode I microfractures in quartz grains. The fractures are cemented and are seen as lines of small inclusions. There are two approximately perpendicular sets of microfractures. Sample from $1282 \mathrm{~m}$. Length of photomicrograph is $4.3 \mathrm{~mm}$. (b) Mode I microfracture, $0.5 \mathrm{~mm}$ wide with laumontite fracture filling. Sample from $1879 \mathrm{~m}$. Length of photomicrograph is $2.15 \mathrm{~mm}$. 


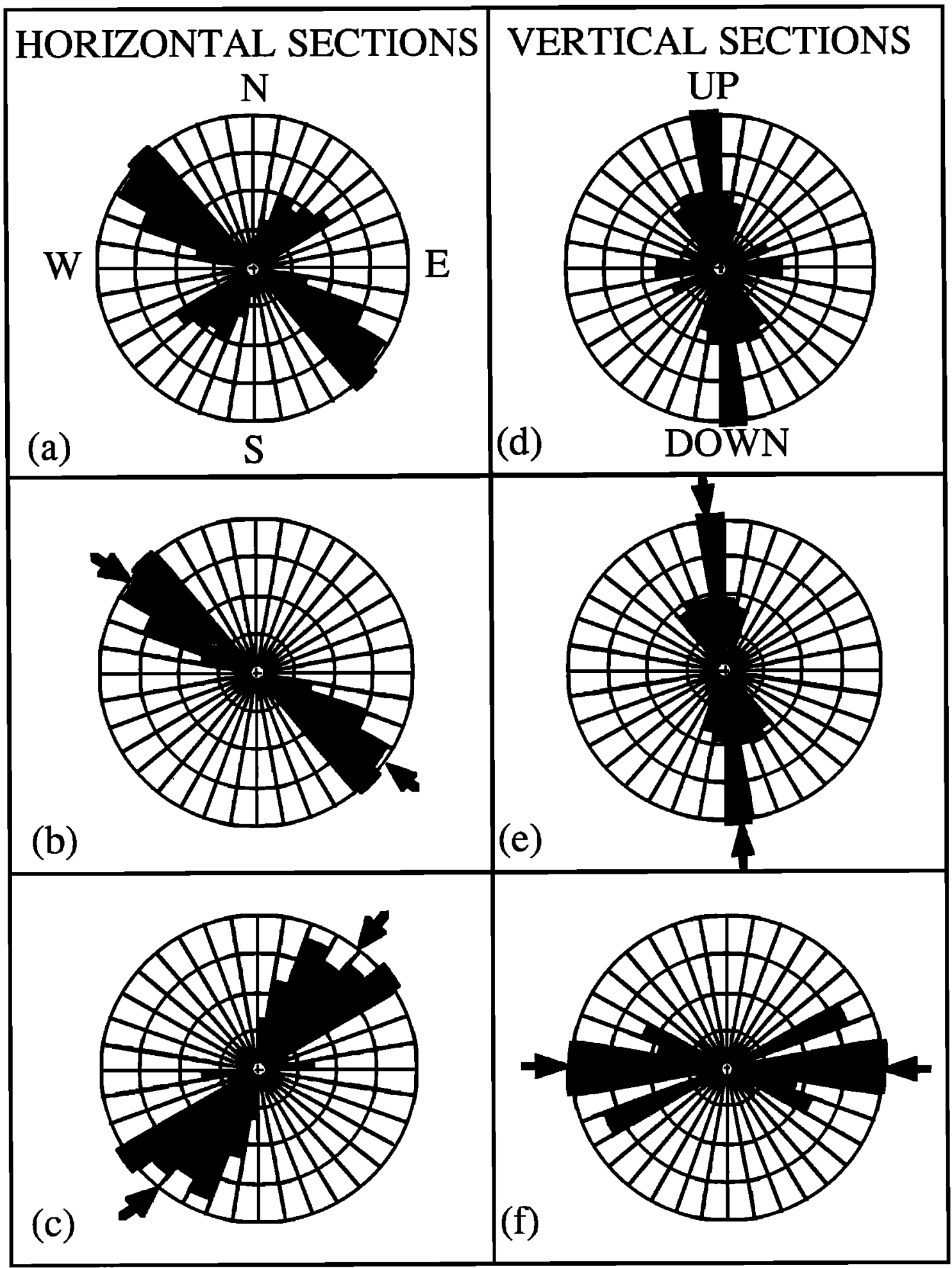

Fig. 3. Rose diagrams of microfracture density orientations measured in thin sections between 521 and $1744 \mathrm{~m}$ depth. The number orientations have been weighted by the square of the lengths of the microfractures. Each diagram is variably scaled so that the longest. petal represents the proportion of the data in the maximum $10^{\circ}$ sector. The arrows show vector means of data subsets. $(a)$ The total data set in horizontal sections, 862 fractures. The longest petal of the rose diagram represents $15.9 \%$ of the data. (b) The northwest striking subset of the horizontal data., vector mean $307^{\circ}$. Longest petal $=28 \%$. (c) The northeast striking subset of the vertical data, vector mean $040^{\circ}$. Longest petal $=20 \%$. $(d)$ The total data set in vertical sections, 440 fractures. Longest petal $=20 \%$. $(e)$ The vertical subset of the vertical data, vector mean dip $=94^{\circ}$. Longest petal $=30 \%$. $(f)$ The horizontal subset of the vertical data, vector mean dip $=2^{\circ}$. Longest petal $=23 \%$. 
majority of microfractures are within $20^{\circ}$ of vertical, and there is a smaller subhorizontal set (Figures $3 e$ and $3 f$ ). The distribution of orientations with depth is shown in Figures 4 and 5, which illustrate some variability in the orientations, and large variations in the relative density of each set, even within a single core. The number of microfractures/area $(M)$ has a range of $0.01-0.2 \mathrm{~mm}^{-2}$ and gives a range of $0.01-0.4$ for the microfracture density parameter $(\varepsilon)$, with an average of 0.12 (Table 1 ).

Mode I fractures with lengths greater than $25 \mathrm{~mm}$ occur throughout the study interval. They range up to several meters in length and several tens of millimeters in width (Table 1) and are commonly filled by calcite and zeolites (Figure $2 b$ ) [James and Silver, 1988]. A distinct fracture filling of epidote-chlorite-quartz occurs in some fractures that have irregular margins and may be arranged in an en echelon geometry. The fracture orientations are similar to the microfractures: two sets of vertical fractures with north west and northeast strikes are observed (Figure 6). No estimate of the fracture density is possible since they lie approximately parallel to the drill hole. There is a complete range of sizes between microfractures and fractures. Microfracture and fracture sets have similar orientations and filling materials at any point.

There is a clear age relationship between the fracture/microfracture sets. Laumontite and/or calcite sets always cut epidote-chlorite-

$\operatorname{Depth}(\mathrm{m})$

524
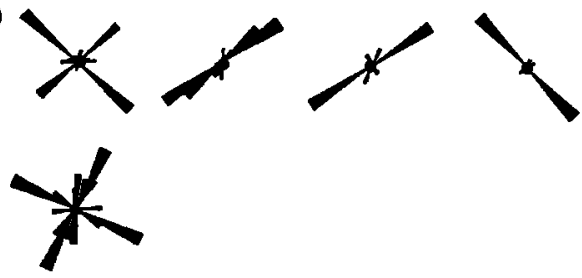

706
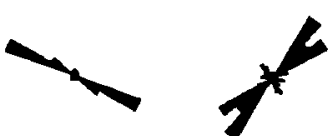

1024
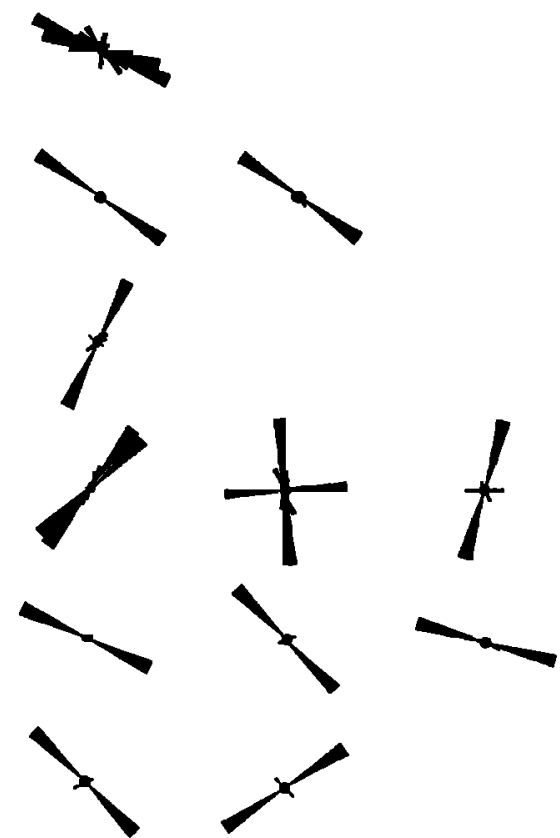

Fig.4. Rose diagrams of microfracture density orientations with depth in horizontal sections. The clear separation of northwest and northeast sets is apparent, and there is some nonsystematic variability with depth. One of the sets is usually subordinate or even absent in any single section. Scaling as in Figure 3.

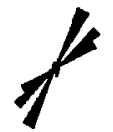

Depth(m)
524
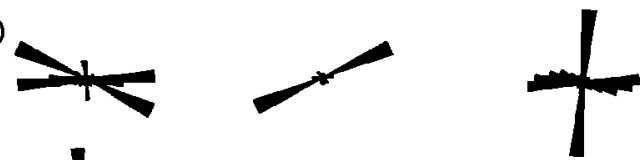

595

706
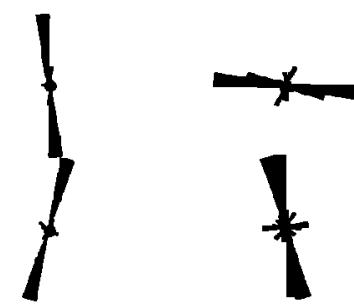

VERTICAL

1024

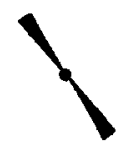

1285
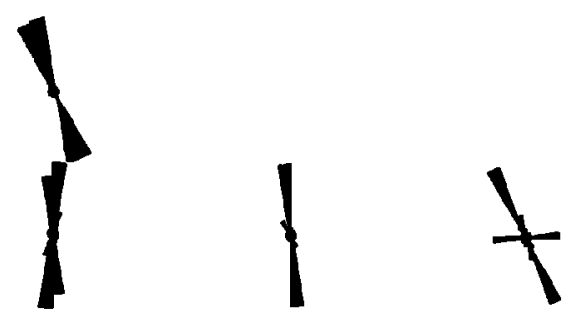

Fig.5. Rose diagrams of microfracture density orientations in vertical sections. All diagrams show the most common vertical orientation; there is also subhorizontal set in some cases. Scaling as in Figure 3.

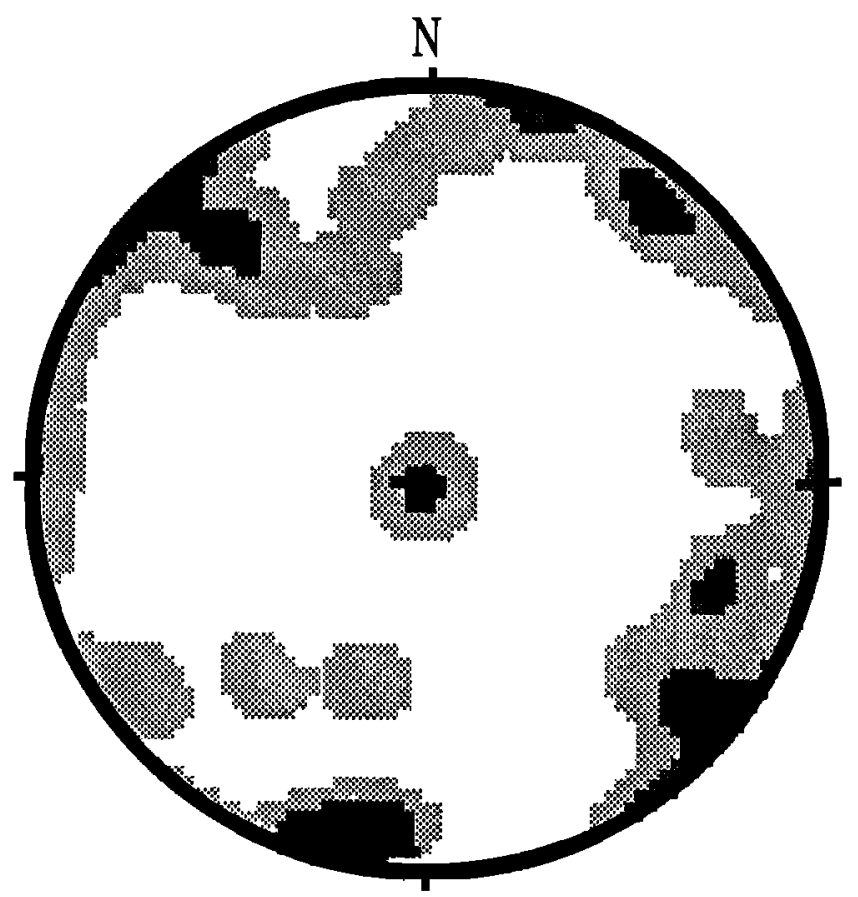

Fig. 6. Lower hemisphere equal-area contoured stereogram of poles to mode I fractures measured directly from the core in the same interval, showing two sets in vertical, NW-SE and NE-SW orientations. Contour intervals in points $/ 1 \%$ area: $1-4,4-7,7-10.5$. 
quartz sets, although earlier fractures have been refractured in some instances. Mode I fractures and microfractures are clearly cut and offset by reverse shear fractures at several points throughout the core. These in turn are cut and displaced by high-angle shear fractures with normal components. The role of these shears in dating the chronology of the fractures is discussed below.

A summary description of the microfracture characteristics of the drill hole is shown in Figure 7 for the more restricted interval 1300 $1700 \mathrm{~m}$ (cores 17-19). The orientation of the two microfracture sets has been determined by dividing the total microfracture density orientations into two sets along N-S and E-W lines and taking the vector means of the subsets. The crack density parameters were calculated by dividing the total microfracture density between the two sets in the ratio of their relative densities.

\section{Comparison of Measured Fracture/Microfracture Orientations With Observed Seismic Anisotropy}

Directions of seismic polarization observed in two of the vertical seismic profile (VSP) experiments are summarized in Figure 8 for the depth interval 750-1820 m. The first column shows results of experiments by Daley et al. [1988] in which two clear polarizations were observed. They used a shear wave vibrator in three azimuths together with a $P$ wave source and VSP recording to analyze particle motions. These showed clear polarization directions approximately parallel and perpendicular to the strike of the San Andreas fault, i.e., in NW-SE and NE-SW directions, between 750 and $1000 \mathrm{~m}$. The first motions were in the NW-SE direction. Microfracture orientations measured within this interval at $742 \mathrm{~m}$ show a dominant microfracture set with the same orientation (Figure 4), which is similar to the orientation of the main microfracture set measured immediately above and below this depth.

Daley et al. [1988] also observed clear polarization directions between 1300 and $1400 \mathrm{~m}$ in the same orientations, but with the first arrival in the NE-SW direction. Li et al. [1988] made VSP recordings in the interval $1300-1800 \mathrm{~m}$ from a $P$ wave vibrator in two source positions. They detected anisotropy in converted $P$ to $S$ waves with the most coherent traces of the faster wave at an orientation of $070^{\circ}$, which they interpret to indicate a fracture fabric in this direction. Within the range of variation in microfracture orientation and allowing for uncertainty in core orientation, these polarizations correspond to the orientation of one of the microfracture sets seen in the combined orientation measurements for this interval, as illustrated in Figure 7. Li et al. [1988] also use Hudson's [1981] description of velocity dependence on the elastic properties of a fractured rock to deduce that a monoplanar fracture array orientated at an azimuth of $070^{\circ}$, with a crack density parameter of $0.02-0.03$, models their results between the intervals of 1300 and $1800 \mathrm{~m}$. This is comparable with the measured density of the microfracture set in this orientation (Figure 7). Bush and Crampin [1988] report polarization directions of $060^{\circ}$ from these VSP data. Fracture orientations are also parallel to the polarization directions of the shear waves (Figure 6).

\section{Discussion}

The correspondence between the fracture/microfracture orientations and polarization directions shows that they control the anisotropy. The orientation of the dominant microfractures evidently switches frequently between the northwest and northeast sets down the core due to variations in relative fracture density. These changes

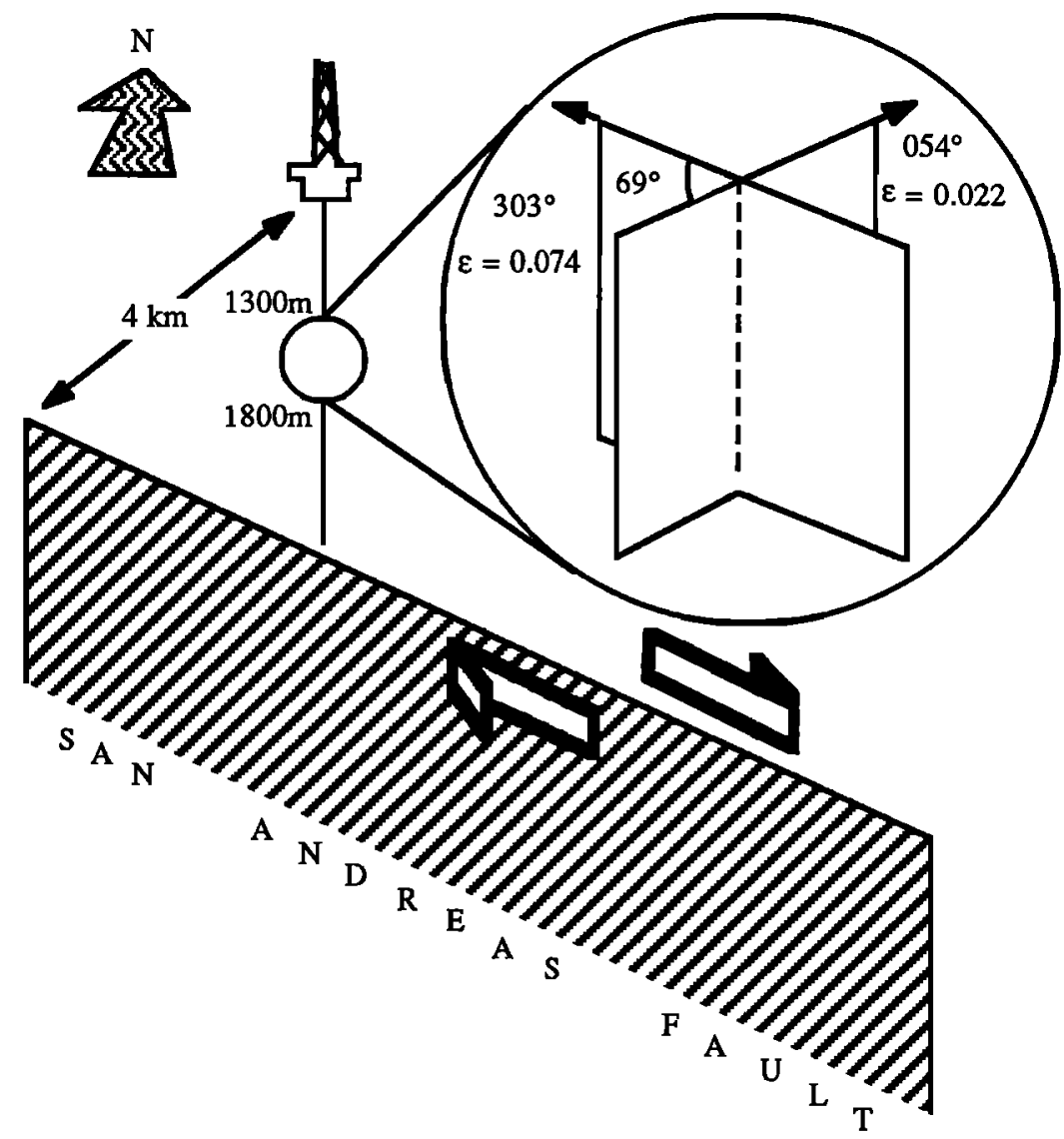

Fig. 7. Description of microfractures in the crystalline basement of the Cajon Pass drill hole from 1300 to $1800 \mathrm{~m}$. The vector mean orientation and microfracture densities $(\varepsilon)$ of the two microfracture sets are shown. 


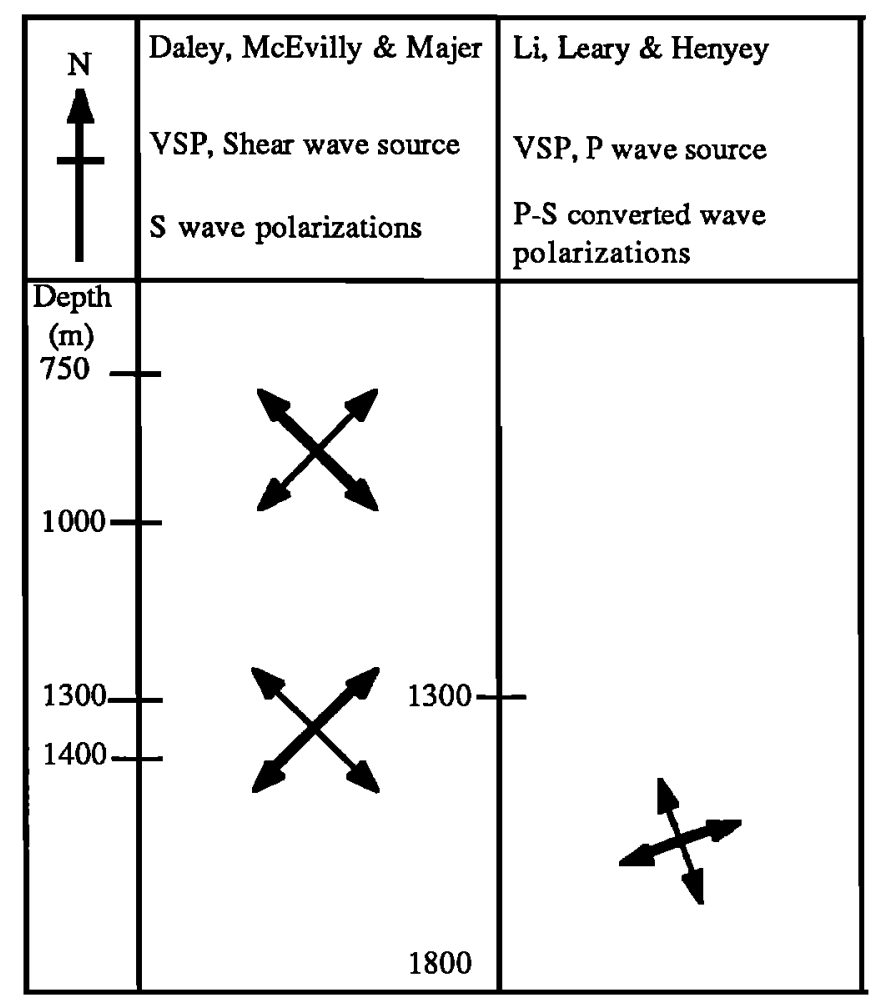

Fig. 8. Polarization directions observed in the Cajon Pass drill hole. The arrows indicate polarization directions in the horizontal plane. The thicker arrow indicates the first motion.

can occur within a single core on a scale of centimeters, for example in core 5 at $524 \mathrm{~m}$ and core 19 at $1655 \mathrm{~m}$ (Figure 4). Similar changes are seen in the fast polarization direction, which may not always coincide with the orientation of the most dense microfracture set in the nearest core measurement because of this small-scale variation.

In greater detail, many of the hodograms of Daley et al.[1988] show complex and elliptical particle motions. Liu and Crampin [this issue] have recently examined the effect of internal interfaces on shear waves by full wave modelling. As the angle of incidence between the ray path and the interface normal is increased, particle motions become increasingly distorted due to the interface. The lower angles of incidence for which particle motions are unaffected by the interface define an "internal shear wave window." Below an isotropic/anisotropic interface, the initial directions of particle motion are virtually unaffected by the interface within the internal shear wave window, so that the effects of anisotropy can be clearly distinguished from those due to the interface. With lengthening ray path in the anisotropic material, the effects of the anisotropy increase and subsequent particle motion becomes elliptical. Outside the internal shear wave window, elliptical motion occurs, just as in the isotropic case. These results suggest that elliptical motions observed by Daley et al. at shallow depths may be due to interface effects where the ray path could be outside the internal shear wave window because of higher angles of incidence from the offset shear wave source to sub horizontal interface normals. Several subhorizontal interfaces are known from core and log data in the upper part of the drill hole, such as the sheared sediment basement contact at $488 \mathrm{~m}$, possibly intrusive contacts between granite and granodiorite at 900 $\mathrm{m}$ and between granodiorite and gneiss at $1090 \mathrm{~m}$ [Silver and James, 1988]. There are also direct seismic expressions of such interfaces [Leary et al., 1988, 1989].

The microfracture observations reported here can be compared with the study of a similar number of microfractures by Wang and
Sun [this issue], restricted to depths of 743-746 and 1283-1286 m (cores 10 and 16), in which microfractures were counted and their orientations were also measured directly with an optical microscope equipped with a mechanical stage. Microfractures were also described using scanning electron microscopy and EDS microchemical analysis. Wang and Sun [this issue] report a dominant microfracture set with a mean orientation of $338^{\circ}$ (their set 1 ), a subordinate set at $043^{\circ}$ (set 2), and a minor set at $072^{\circ}$ (set 3 ) in core 10 . The most recent fractures are set 1 , which are described as "generally empty." Microfracture number orientations of this study (rather than the density orientations that are shown in Figures 3,4, and 5) are directly comparable with these measurements and also show a NNW orientated fracture set in core 10; however, these microfractures are partially cemented and do not post-date other sets of microfractures. Set 2 of Wang and Sun [this issue] correspond in description and orientation to the northeast set of this study. There was no evidence of their minor set 3 . These authors did not reportmicrofractures in the dominant northwest orientation as observed here. Both studies see essentially the same microfracture number distribution in core 16 .

Large variations in individual sample measurements suggest that discrepancies between microfracture number distributions in core 10 probably arise because of the heterogeneous distribution noted above. Even two samples from the same core yield different densities of microfracture sets, to the extent that a complete fracture set may be absent from adjacent samples. An accurate overall description would require very extensive sampling. Since this study reports a set of cemented microfractures in the set 1 orientation, it is possible that some of the open microfractures observed by Wang and Sun may be refractured along earlier, cemented microfractures. However, weighting the microfracture distributions by area emphasizes the importance of the northwest and northeast sets and suggests that the NNW set (set 1) may be insignificant in terms of anisotropy.

Mode I fractures reported here are similar to laumontite veins described from surface outcrops by Vincent and Ehlig [1988]. The orientation of 284 veins from the Cajon Valley northeast of the San Andreas fault also showed high dips with a dominant concentration of northeast strikes and a weaker northwest set, similar to the two fracture orientations described earlier.

It is important to evaluate the relative contributions of different types of fractures and microfractures to seismic anisotropy. Intragranular microfractures may contribute less to anisotropy because they consist of planes of isolated pores or fluid inclusions separated by continuous silica cement. Larger mode I microfractures and fractures observed in the core material have continuous weak fillings (zeolites, calcite, fluids), giving them characteristics similar to saturated fractures that are more significant for seismic anisotropy.

It is also important to assess any differences between the core samples and the in situ physical properties of the rock. Confining pressure closes fractures, as demonstrated in several laboratory studies. These studies also indicate that preexisting fractures can stay open to significant depths in the crust; Kern [1988], for example, suggests that fracture closure in a variety of metamorphic rocks is complete only at confining pressures of $200 \mathrm{MPa}$, corresponding to depths of $8 \mathrm{~km}$, and Coyner [1988] reports reduction in anisotropy of Chelmsford Granite up to confining pressures of $80 \mathrm{MPa}$. The effects of confining pressure on anisotropy will be complicated by the preferential closure of fractures orientated such that they experience higher normal stress [Nur, 1988; Sayers, 1988]. The experiments indicate that fractures remain partially open at the depths of the seismic anisotropy measurements $(500-1800 \mathrm{~m})$.

The fracture/microfracture aspect ratios may also differ from the measured values of materials in the in situ environment. Crampin et al. [1986], Peacock et al. [1988], and Douma and Crampin [this issue] illustrate how aspect ratio has an important effect on velocities 
of waves that intersect a single set of fractures, using an analysis that explicitly considers the effect of aspect ratios. The range of aspect ratios measured in this study overlaps with the range that influences the models of Douma and Crampin [this issue] $\left(1 \times 10^{-4}-1 \times 10^{-1}\right)$. In situ values are likely to be larger than the measured values due to the effects of contacts at asperities and fracture fillings. The models show that velocities of the two $S$ waves become equal and the leading shear wave has a sudden change of polarization in some propagation directions. Within the range of aspect ratios given above, the ciritcal propagation directions are a function of aspect ratio, but for sufficiently large aspect ratios, the velocities remain completely separate in all orientations [Douma and Crampin, this issue]. Changes in relative aspect ratios of the two dominant fracture/microfracture sets with depth could therefore also cause changes in the polarization direction of the leading shear wave.

There is some independent evidence for the nature and role of the fractures at depth. Hirsch andWang [1988] determined that resistivities of 3.8-cm-diameter plugs cut from cores recovered from depths of less than $1600 \mathrm{~m}$ were an order of magnitude greater than in situ resistivities and ascribed this result to fractures filled by either fluids or conductive materials such as zeolites, clays, or sulphides. The in situ measurements were made with the deep laterolog tool, which measures resistivity on a scale of several meters [Pezard et al., 1988]. This indicates the importance of meter-scale fractures. Slightly below the study interval at depths of $1829-2115 \mathrm{~m}$, fluids at pressures $5 \%$ greater than hydrostatic were measured by Coyle and Zoback [1988]. These lines of evidence suggest that large fractures with weak or fluid fillings are important in the drill hole environment.

A minimum age for the formation of the mode I fractures/microfractures is suggested by two arguments based on the regional tectonic history deduced by Meisling and Weldon [1989]. From late Miocene to early Pliocene, NNE-SSW shortening resulted in the development of the Squaw Peak thrust system. Sediments of the Crowder formation were thrust over the Cajon formation along the Squaw Peak thrust fault, and the Cajon Basin sediments were affected by penetrative cataclastic shortening and folding. During the middle Pleistocene, deformation was localized uplift within a few kilometers of the San Andreas fault, forming the San Bernardino arch. The drill hole is situated in the footwall of the Squaw Peak thrust (and probably in the hanging wall of related thrusts), approximately $0.5 \mathrm{~km}$ west of a N-S trending segment that Meisling and Weldon interpret as a lateral ramp. Reverse shear fractures that cut the mode I fractures/microfractures were most plausibly formed during the late Miocene-early Pliocene as minor splays and backthrusts of the Squaw Peak thrust system. They have the same style of penetrative cataclasis seen along the Squaw Peak thrust itself. This style is not associated with the subsequent uplift of the San Bernardino arch ( $R$. Weldon, personal communication, 1988), which suggests lateMiocene-early Pliocene as a minimum age for the mode I fractures/microfractures. Although sediments of the Cajon Pass formation were also folded by this deformation, the dominan northwest striking, vertical set of fractures observed by Vincent and Ehlig [1989] preserves a good preferred orientation since they are normal to the horizontal northwest trending fold axis. Likewise, the strikes of the northeast striking microfractures are unaffected by this folding.

The stability field of laumontite places constraints on the depth and age of formation of laumontite fracture fills. James and Silver [1988] estimate that laumontite is stable and forming at a minimum depth of $2100 \mathrm{~m}$ in the well at present. They also argue for an early age of laumontite in the upper part of the drill hole from the zonation of zeolites and the presence of radiation damage haloes in zeolites. Vincent and Ehlig [1988] suggest a depth of $2.5-3.5 \mathrm{~km}$ for laumontite formation. This amount of uplift occurred throughout the Pleis- tocene according to Meisling and Weldon [1989] and implies that the laumontite probably has a minimum Pliocene age.

Shear fractures with normal components are observed cutting the reverse shear fractures, and also fit this regional deformation chronology. Weldon and Springer [1988] deduce a period of late Quaternary normal slip on the Cleghom fault ( $1 \mathrm{~km}$ southwest of the drill hole) and several other faults between the Cleghom and San Andreas faults. Focal mechanism solutions for earthquakes in the San Bernardino segment of the San Andreas fault zone show normal faulting with a WSW, horizontal, least principal stress [Jones, 1988]. Weldon and Springer [1988] suggest that this segment may extend to north of Cajon Pass, as permitted by the seismic data. The normal faulting observed in both the basement and sedimentary rocks in the drill hole can be linked to this most recent tectonic episode.

Experimental evidence shows that microfracture healing rates in quartz can be extremely rapid [Smith and Evans, 1984]. Healing rates depend on temperature and inversly on initial concentration of silica in the fluid. Taking the low and high values of initial silica concentration used in the experiments of Smith and Evans, the time required to heal a typical $1-\mathrm{mm}$-long microfracture calculated using the present day in situ temperature of the well [Lachenbruch and Sass,1988] is 12 and 18,000 years, respectively. Silica concentrations measured in the drill hole indicate that fluids are silica saturated [Kharaka et al., 1988; Barnes, 1967], so that the longer estimate is probably more appropriate. It would therefore be possible to generate some of the healed microfractures in the neotectonic stress field. However, the cross cutting relations and petrological evidence documented above suggest that a majority were formed in an earlier tectonic event. A major difficulty in applying the experimental results to the drill hole is the unknown effect of confining pressure. The experiments were carried out at $200 \mathrm{MPa}$, compared to pressures of only a few tens of megapascals in the drill hole.

\section{Conclusions}

Fractures and microfractures in cores from the Cajon Pass drill hole have two strong preferred orientations. They have northwest and northeast strikes and vertical dips. The orientation of the dominant microfracture set switches between NE and NW on a small scale because of large variations in the densities of each set. Seismic anisotropy is caused by the fractures/microfractures, which were probably formed before a late Miocene-Pliocene deformation episode and are not directly related to the modem San Andreas fault or formed by the in situ stress field. The complexity of the seismic particle motions suggests that full wave modelling, accounting for possible interface effects and changing aspect ratios, combined with the fracture/microfracture orientation data, would be useful approach to modelling the details of the anisotropy.

Acknowledgments. Part of this work was supported by the National Science Foundation under grant DAR-84-10924 and DOSSEC under subcontract DSC-4-86. The guidance of Peter Leary in revising this paper is gratefully acknowledged. Stuart Crampin and Peter Malin are thanked for their constructive criticism and suggestions, Eric James and Chi-Yuen Wang for their reviews, and Rick Sibson and Craig Nicholson for their comments.

\section{REFERENCES}

Babuska, V., and Z. Pros, Velocity anisotropy in granodiorite and quarzite due to the distribution of microcracks, Geophys. J. R. Astron. Soc., 76, 121-127, 1984.

Bames, H. L. (Ed.), Geochemistry of Hydrothermal Ore Deposits, 670 pp., Holt, Rinehart and Winston, New York, 1967.

Bennett, H. F., and S. B. Smith, Shear wave birefringence as indicated on three component seismic data from the Mammoth Lakes, Califomia, Earthquake Sequence of May-Jume 1980, paper presented at Chapman 
Conference on Seismic Anisotropy in the Earth's Crust, AGU, Berkeley, Calif., May 31 to June 4, 1988.

Blenkinsop, T. G., and E. H. Rutter, Cataclastic deformation of quartzite in the Moine thrust zone, J. Struct. Geol., 8, 669-681, 1986.

Blenkinsop, T. G., and R. H. Sibson, Deformation mechanisms and stress history near the San Andreas fault in the Cajon Pass drill hole, Eos Trans. $A G U ., 69,1449,1988$.

Bush, I., and S. Crampin, Synthetic modelling of a Cajon Pass $P$ wave VSP, California, paper presented at the Chapman Conference on Seismic Anisotropy of the Earth's crust, Lawrence Berkeley Lab., Berkeley, Calif., May 31 to June 4, 1988.

Coyle, B. J., and M. D. Zoback, In-situ permeability and fluid pressure measurements at -2 km depth in the Cajon Pass research well, Geophys. Res. Lett., 15, 1029-1032, 1988.

Coyner, K. B., Laboratory measurements of elastic anisotropy in dry and saturated Chelmsford granite, paper presented at Chapman Conference on Seismic Anisotropy in the Earth's Crust, AGU, Berkeley, Calif., May 31 to June 4, 1988.

Crampin, S., Seismic wave propagation through a cracked solid: polarization as a possible dilatancy diagnostic, Geophys. J.R. Astron. Soc., 53, 467-496, 1978.

Crampin, S., A review of wave motion in anisotropic and cracked elastic media, Wave Motion, 3, 343-391, 1981.

Crampin, S., An introduction to wave propagation in anisotropic media, Geophys.J. R. Astron. Soc., 76, 17-28, $1984 a$.

Crampin, S., Effective anisotropic elastic constants for wave propagation through cracked solids, Geophys. J. R. Astron. Soc., 76, 135-145, $1984 b$.

Crampin, S., and S. C. Kirkwood, Velocity variations in systems of anisotropic symmetry, J. Geophys., 49, 35-42, 1981.

Crampin, S., R. Evans, B. Ucer, M. Doyle, J. P. Davis, G. V. Yegorkina, and A. Miller, Observations of dilatancy-induced polarization anomalies and earthquake prediction, Nature, 286, 874-877, $1980 a$.

Crampin, S., R. McGonigle, and D. Bamford, Estimating crack parameters from observations of $P$ wave velocity anisotropy, Geophysics, 45, 345 $360,1980 b$.

Crampin, S., R. Evans, and B. K. Atkinson, Earthquake prediction: A new physical basis, Geophys. J. R. Astron. Soc., 76, 147-156, 1984.

Crampin, S., R. McGonigle, and M. Ando, Extensive dilatancy anisotropy beneath Mount Hood, Oregon, and the effect of aspect ratio on seismic velocities through aligned cracks, J. Geophys. Res., 91, 703-712, 1986.

Crampin, S., D. Booth, J. R. Evans, S. Peacock, and J.B. Fletcher, Changes in shear wave splitting at Anza near the time of the North Palm Springs earthquake, J. Geophys. Res., this issue.

Daley, T. M., T. M. McEvilly, and E. L. Majer, Multiply-polarized shearwave VSPs from the Cajon Pass drill hole, Geophys. Res. Lett., 15, 1001 $1004,1988$.

Davis, E. E., and R. M. Clowes, High velocities and seismic anisotropy in Pleistocene turbidites off westem Canada, Geophys.J.R.Astron. Soc., 84 $381 \cdot 399,1986$

Douma, J., and S. Crampin, The effect of a changing aspect ratio of aligned cracks on shear wave vertical seismic profiles: A theoretical study, $J$ Geophys. Res., this issue.

Evans, R., Anisotropy: A pervasive feature of fault zones?, Geophys.J.R. Astron. Soc., 76, 157-163, 1984.

Hirsch, L. M., and C.-Y. Wang, Electrical resistivity of Cajon Pass cores at elevated pressures, Geophys. Res. Lett., 15, 1025-1928, 1988.

Hudson, J. A., Overall properties of a cracked solid, Math. Proc. Cambridge Philos. Soc., 88, 371-384, 1980.

Hudson, J. A., Wave speeds and attenuation of elastic waves in material containing cracks, Geophys. J. R. Astron. Soc., 64, 135-150, 1981.

James, E. W., and L. T. Silver, Implications of zeolites and their zonation in the Cajon Pass deep drill hole, Geophys. Res. Lett., 15, 973-976, 1988.

Jones, L. M., Focal mechanisms and the state of stress on the San Andreas fault in southem California, J. Geophys. Res., 93, 8869-8891, 1988.

Kharaka,Y. K., G. Ambats, W. C. Evans, and A. F. White, Geochemistry of water at Cajon Pass, Califomia: Preliminary results, Geophys. Res. Lett., 15, 1037-1040, 1988

Kem, H., Fabric-related anisotropy of seismic wave velocity and shear wave splitting in crustal rocks: Evidence from laboratory studies, paper presented at the Chapman Conference on Seismic Anisotropy of the Earth's Crust, Lawrence Berkeley Lab., Berkeley, Calif., May 31 to June 4, 1988.
Lachenbruch, A. H., and J.H. Sass, The stress heat-flow paradox and thermal results from Cajon Pass, Geophys. Res. Lett., 15, 981-984, 1988.

Leary, P. C., T. L. Henyey, and Y.-G. Li, Fracture related reflectors in Basement rock from vertical seismic profiling at Cajon Pass, Geophys. Res. Lett., 15, 1057-1060, 1988.

Leary, P.C., T.L. Henyey, and Y.-G. Li, Vertical seismic profiling at Cajon Pass (abstract), Eos Trans. AGU, 70, 481, 1989.

Li, Y.-G., P. C. Leary, and T. L. Henyey, Stress orientation from shear wave splitting in basement rock at Cajon Pass, Geophys. Res. Lett., 15, 997 $1000,1988$.

Liu, E., and S. Crampin, Effects of the intemal shear wave window: Comparison with anisostropy-induced splitting, J. Geophys. Res., this issue.

Maslova, S. I., and I. R. Obolentseva, An anisotropic model of the Earth's crust in the Baikal rift zone, Geophys. J. R. Astron. Soc., 76, 227-232, 1984.

Meisling, K. E., and R. J. Weldon, The late Cenozoic tectonics of the northwestem San Bernardino mountains, southem Califomia, Geol. Soc. Am. Bull., 101, 106-128, 1989.

Morrow, C., and J. Byerlee, Permeability of rock samples from Cajon Pass, California, Geophys. Res. Lett., 15, 1033-1036, 1988.

Nitikin, L. V. and E. M. Chesnokov, Wave propagation in elastic media with stress-induced anisotropy, Geophys. J. R. Astron. Soc., 76, 29-133, 1984.

Nur, A., Crustal velocity anisotropy: The opening of dilatant cracks, or the closure of pre-existing ones?, paper presented at the Chapman Conference on Seismic Anisotropy of the Earth's Crust, Lawrence Berkeley Lab., Berkeley, Calif., May 31 to June 4, 1988.

$O^{\prime}$ Connell, R. J., and B. Budiansky, Seismic velocities in dry and saturated cracked solids, J. Geophys. Res., 79, 5412-5426, 1974.

Peacock, S., S. Crampin, and D. C. Booth, Shear wave splitting in the Anza seismic gap, southem Califomia: Temporal variations as possible precursors. J. Geophys. Res., 93, 3339-3356, 1988.

Pezard, P. A., and S. M. Luthi, Borehole electrical images in the basement of the Cajon Pass scientific drill hole, Califomia: Fracture identification and tectonic implications, Geophys. Res. Lett., 15, 1017-1020, 1988.

Pezard, P. A., R. N. Anderson, J. J. Howard, and S. M. Luthi, Fracture distribution and basement structure from measurements of electrical resistivity in the basement of the Cajon Pass scientific drill hole, Califomia, Geophys. Res. Lelt., 15, 1021-1024, 1988.

Rector, J. W., Acquisition and preliminary analysis of orientated multicomponent multioffset VSP data: Dosecc Cajon Pass deep scientific drill hole, Geophys. Res. Lett., 15, 1061-1064, 1988.

Savage, M. K., W. A. Peppin, and U. R. Vetter, Shear wave anisotropy and stress direction in and near Long Valley Caldera, California, 1979-1988, J. Geophys. Res., this issue.

Sayers, C. M., Microcrack induced seismic anisotropy, paper presented at Chapman Conference on Seismic Anisotropy of the Earth's Crust, AGU, Berkeley, Calif., May 31 to June 4, 1988.

Silver, L. T., and E. W. James, Geologic setting and lithologic column of the Cajon Pass deep drillhole, Geophys. Res. Lett., 15, 941-944, 1988.

Smith, D. L., and B. Evans, Diffusional crack healing in quartz, J.Geophys. Res., 89, 4125-4135, 1984.

Vincent, M. W., and P. E. Ehlig, Laumontite mineralization in rocks exposed north of San Andreas fault at Cajon Pass, southem Califomia, Geophys. Res. Lett., 15, 977-980, 1988.

Wang, C.-Y., and Y. Sun, Oriented microfractures in Cajun Pass drill cores: Stress field near the San Andreas fault, J. Geophys. Res., this issue.

Weldon, R. J., and J. E. Springer, Active faulting near the Cajon Pass well, southem California: Implications for the stress orientation near the San Andreas fault, Geophys. Res. Lett., 15, 993-996 1988.

Zoback, M. D., L. T. Silver, T. Henyey and W. Thatcher, The Cajon Pass scientific drilling experiment: Overview of phase 1, Geophys. Res. Lett., $15,933-936,1988$.

T. G. Blenkinsop, Department of Geology, University of Zimbabwe, P. O. Box MP 167, Mount Pleasant, Harare, Zimbabwe

(Received January 3, 1989; revised December 5, 1989; accepted December 21, 1989.) 